organ where $\mathrm{T}$ lymphocytes differentiate. With development of monoclonal antibody the differentiating antigens on human thymocytes and $\mathrm{T}$ lymphocytes have been studied. A subset of $T_{1,3,5}$ lymphocytes exerts suppressor function and cytotoxicity whereas another subset of $T_{1,3,4}$ lymphocytes mounts the proliferative response to soluble antigens and helper function.

Regulatory $\mathrm{T}$ cells are known to be heterogenous. They are antigen-specific or antigen-nonspecific. Some are isotype-, allotype- or idiotype specific helper or suppressor. IgE-specific Th and Ts were first found by $\operatorname{Dr} \mathrm{T}$. Kishimoto who will present the results on IgE-specific immune responses and its possible regulations.

An individual elicits a regulated immune response to an antigenic stimulation via cell-to-cell interaction. The duration and magnitude of the immune response are controlled by an immune network. An antigen stimulation activates Th to help B lymphocytes proliferate and differentiate into antibody-producing cells. On the other hand it also causes activation of suppressor inducer with phenotype of Lyt, 1, Qa-1 which results in induction of suppressor effector with Lyt, 2, 3 via activation of acceptor cells with phenotype of Lyt, 1, 2, 3, Qa-1. In turn the suppressor effector inactivates Th and thus feedback suppression circuit is formed. Although various mechanisms concerning the pathogenesis of autoimmune diseases are postulated, much attention has recently been paid to the polyclonal $\mathrm{B}$ cell activation and abnormality of feed back suppression. From the view point of these consideration, Drs Sakane and Tanimoto will present the papers on immune dysfunction of lymphocytes of SLE and other related diseases. Abnormality of the immune network also results in the immuno-deficiency. Dr Mitsuya will present the data on cellular defects and dysfunction of primary immunodeficiencies.

Immunoglobulin combines an antigen to its combining site that exhibits unique antigenic determinants called idiotype. An idiotype is also recognized by an anti-idiotype antibody. Recently an idiotype is also found on $\mathrm{T}$ cells. Thus a idiotype and anti-idiotype system including immunoglobulins, B and $\mathrm{T}$ cells forms a closed network that regulate the immune response. Dr Sugai will present the papers on the clinical significance of idiotype in monoclonal hypergammaglobulinemia.

\title{
(1) Regulation of the IgE Antibody Response
}

\author{
Tadamitsu Kishimoto, MD \\ Osaka University, Medical School
}

\section{INTRODUCTION}

The identification of $\operatorname{IgE}$ as a carrier of reaginic antibody activity has greatly contributed to the understanding of the mechanism of reaginic hypersensitivity reactions. A crucial role of $\operatorname{IgE}$ antibody in allergic diseases suggests to us that understanding of the controlling mechanisms operating in the $\operatorname{IgE}$ response is the goal that must be reached for the development of new therapeutic approaches to allergic diseases.

In the last decade, cellular mechanisms of the $\operatorname{IgE}$ antibody formation has been much revealed in experimental animals. As observed in IgM or IgG antibody formation, it was shown in mice, rabbits and rats that collaboration of $\mathrm{T}$ and $\mathrm{B}$ lymphocytes was essential for the induction of the $\operatorname{IgE}$ antibody response. Moreover, in the IgE anti- 
body response, the existence of IgE classspecific regulatory $T$ cells that exert their influence selectively on the $\operatorname{IgE}$ response has been suggested. Certain characteristic features of the IgE response that are not easily demonstrated in the IgG or IgM antibody response may be explained by assuming the presence of IgE class-specific helper or suppressor $\mathrm{T}$ cells. If the $\mathrm{IgE}$ antibody response in vivo is really regulated by the balance of $\mathrm{IgE}$ class-specific helper and suppressor $\mathrm{T}$ cells, it is conceivable that induction of an increased number of $\mathrm{IgE}$ class-specific suppressor $\mathrm{T}$ cells may result in the selective diminution of the IgE antibody production, while sparing the antibody productions with other immunoglobulin isotypes.

\section{INDUCTION OF IgE CLASS-SPECIFIC SUPPRESSOR T CELLS}

Selective suppression of the $\operatorname{IgE}$ antibody response was shown by preadministration of DNP-conjugated mycobacterium (DNP$\mathrm{Myc}$ ) into BALB/c mice. As shown in Fig 1, preadministration of DNP-Myc completely inhibited the induction of anti-DNP $\operatorname{IgE}$ response against DNP-OVA without an in- hibitory effect on anti-DNP IgG response. Cell transfer experiment clearly showed that the selective suppression of the IgE response was due to the induction of IgE class-specific suppressor $\mathrm{T}$ cells.

In the experiment described in Fig 2, the suppressor function of DNP-Myc-primed $\mathrm{T}$ cells was shown to be mediated by $\mathrm{IgE}$ class-specific suppressor factors. DNP specific stimulation of $T$ cells induced the production of IgE class-specific suppressor factors and the factors was shown to have the determinants encoded by the $\mathrm{H}-2$ gene complex. The IgE class-specific suppressive activity of the factor could be absorbed with IgE-conjugated Sepharose column but not with $\operatorname{IgM}$ or $\operatorname{IgG}$, indicating that $\operatorname{IgE}$ classspecific suppressor factor could bind with $\mathrm{IgE}$ and the factor showed its selective influence on the $\mathrm{IgE}$ response by binding with $\mathrm{IgE}$ molecules on the surface of $\mathrm{B} \varepsilon$ cells.

\section{ESTABLISHMENT OF IgE CLASS- SPECIFIC SUPPRESSOR T HYBRIDOMA}

Introduction of somatic cell hybridization technique into immunological fields by
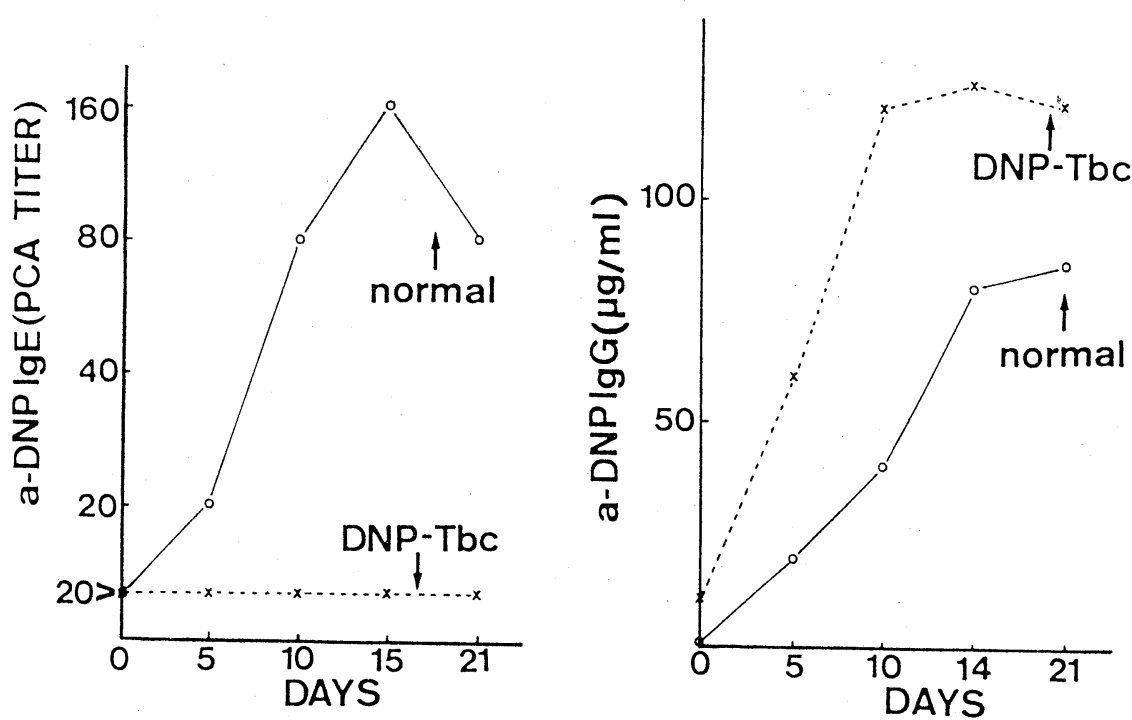

Fig. 1. Selective suppression of anti-DNP IgE response to DNP-OA by preadministration of DNP-Myc. Solid lines ( $\bigcirc-O)$ represent anti-DNP IgE (left) and anti-DNP IgG (right) response in normal mice and dotted lines $(\times \cdots \times)$ show anti-DNP $\operatorname{IgE}(\operatorname{left})$ and IgG (right) response in DNP-Myc-pretreated mice. 

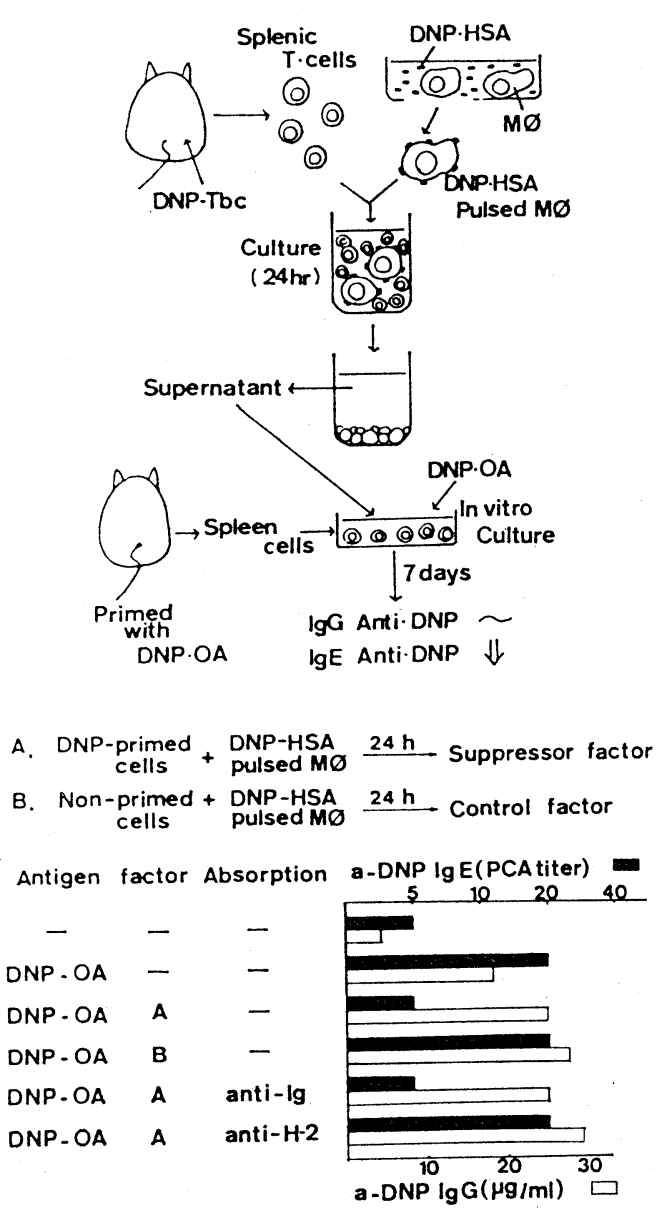

Fig. 2. Selective suppression of in vitro antiDNP IgE response of DNP-OA-primed spleen cells by the addition of culture supernants from coculture of DNP-Myc-primed T cells and DNPHSA-pulsed macrophages.

Köhler and Milstein has provided a revolutionary tool for studies in this field. Their experiments suggested to us that the establishment of a $\mathrm{T}$ hybrid cell line with $\operatorname{IgE}$ class-specific suppressor function could be attained by the hybridization of DNP-Mycprimed $\mathrm{T}$ cells with a $\mathrm{T}$ lymphoma cell line and that establishment of a such cell line would provide a powerful strategy for

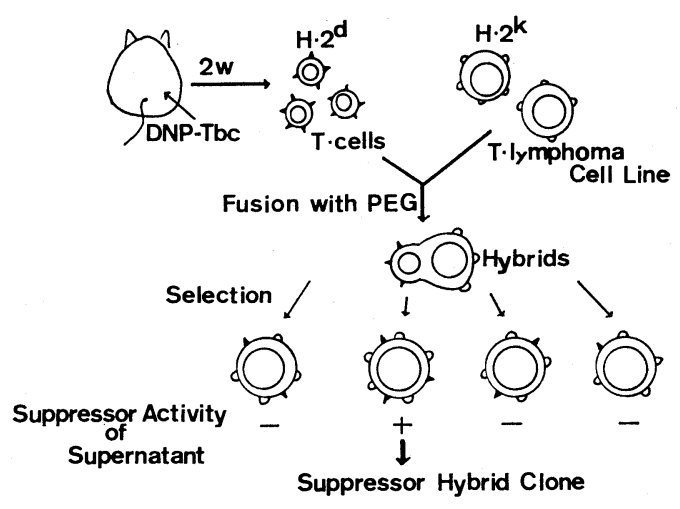

Fig. 3. Establishment of IgE class-specific suppressor $\mathrm{T}$ hybridomas by cell hybridization technique.

the isolation and chemical or immunological characterization of IgE class-specific suppressor factor. By employing the experimental procedures described in Fig 3, we have succeeded in the establishment of a $\mathrm{T}$ hybrid clone secreting $\operatorname{Ig} \mathrm{E}$ class-specefic suppressor function. Some characterizations of the suppressor factor obtained from $\mathrm{T}$ hybridomas were carried out and the result is as follows, i.e. i) suppress the $\mathrm{IgE}$ response but not the IgG response, ii) antigen nonspecific, iii) absorbed with anti-H-2 ${ }^{d}$ antibody, iv) inactivate $\mathrm{B} \varepsilon$ cells but not $\mathrm{T}$ cells, v) absorbed with $\operatorname{IgE}$ but not with $\operatorname{IgG}$ or IgM.

A monoclonal $\mathrm{T}$ cell line secreting $\operatorname{IgE}$ class-specific suppressor factor will be utilized for the isolation and characterization of the suppressor factor. Messenger RNA specific for the suppressor factor will be isolated from a cell line and DNAs encoding the suppressor factor will be cloned. By employing the chemically purified factor, the suppressive mechanisms of the factor will be revealed. If these studies are successfully attained, we will be able to wilfully manipulate human $\operatorname{Ig} \mathrm{E}$ response in a desired fashion. 